\title{
Reducing Book Piracy: The Role of the Higher Education Sector
}

\author{
Evelyn Chiyevo GARWE (Corresponding author) \\ Zimbabwe Council for Higher Education (ZIMCHE) \\ No 21 J.M. Nkomo Road, P. Bag H100 Hatfield Harare, ZIMBABWE \\ Tel: 263-772-222-298Ｅ-mail: garweec@gmail.com / ecgarwe@zimche.ac.zw
}

$\begin{array}{lcc}\text { Received: May 19, } 2014 & \text { Accepted: June 13, } 2014 \quad \text { Published: August 13, } 2014 \\ \text { doi:10.5296/ire.v2i2.5649 } & \text { URL: http://dx.doi.org/10.5296/ire.v2i2.5649 }\end{array}$

\begin{abstract}
The objective of this paper was to address the rampant infringement of intellectual property rights in Zimbabwe, with respect to the literary industry. The paper identifies the various forms of book piracy in Zimbabwe, their causes and effects and strategies to deal with the scourge with specific emphasis on the contribution of the higher and tertiary sector. The methodology included observation, analysis of documentary evidence, and in-depth interviews with key informants inclusive of government officials, higher and tertiary education officials, Zimbabwe International Book Fair leadership, publishers, authors, parents, students and book vendors. The findings revealed that unlawful reprography and abuse of publication rights are the main forms of book piracy in Zimbabwe. The causes of book piracy were identified as book scarcity, poverty and ignorance of the copyright laws. The impact of book piracy was positive as far as the beneficiaries were concerned but had debilitating effects to the copyright owners. The paper suggests ways in which the higher education sector could contribute to the reduction of book piracy initially by their academic staff and students and ultimately by the whole nation through ripple effects. These ways include awareness, advocacy and enforcement of copyright laws; revitalization of libraries as well as encouraging curriculum inclusiveness. The paper contributes to the on-going anti-book piracy debate and provides useful information to Librarians, higher education institutions as well as policy makers.
\end{abstract}

Keywords Book piracy, copyrights, intellectual property, higher education sector, libraries

\section{Introduction}

The last decade witnessed global explosion in counterfeiting, plagiarism and piracy, thereby creating some of the most serious problems facing the world. Reports show that this 
infringement of intellectual property rights has reached unprecedented levels in Zimbabwe (AFP, 2012; Phiri, 2013). There is therefore, an urgent need for conceited efforts to collectively find ways of dealing with this scourge. Although there is general awareness and vigilance on the other illegal practices in Zimbabwe namely; counterfeiting, plagiarism, music and software piracy, there certainly is very little awareness and mitigation against book piracy. Consequently, this paper will focus on issues pertaining only to book piracy.

In Zimbabwe, books remain the main source of knowledge and the main medium of education. The literary industry in Zimbabwe is facing challenges with the rampant piracy of literary materials (AFP, 2012). Efforts to find solutions to curb book piracy saw the Zimbabwe International Book Fair calling on all stakeholders to denounce book piracy and come up with strategies that each sector could employ in order to contribute towards alleviating the problem (Phiri, 2013). Possible strategies on how to reduce piracy and sustain a vibrant book sector were proposed by authors, publishers, booksellers, information users and law enforcement agents. This paper focuses on the contribution of the higher education sector to the national anti-piracy cause.

\subsection{Situating the Higher Education Sector in the Anti-Piracy Debate}

Higher and tertiary institutions are major stakeholders in the piracy debate because most of the intellectuals in these institutions are authors and editors of books and journals articles as well as other scholarly articles. In addition, students, lecturers and library staff commit acts of book piracy (consciously or unconsciously) through photocopying, scanning and printing of copyright material. Higher education institutions are in the business of manpower development. If they produce graduates who are well grounded in the knowledge that piracy is illegal and unethical, the graduates will not only shun piracy but they will also impart this knowledge to the society thereby creating a ripple effect.

\subsection{Explaining Book Piracy}

Piracy was defined by Thomas (1991) as the unauthorised or illegal copying of the work of a protected material belonging to someone else and selling it without benefiting or compensating the rightful holder of the intellectual property. Popoola (1991) defines piracy as the illegal manufacture and distribution, on a commercial scale, of published work without the permission of the copyright owners.

There exist three types of book piracy practised worldwide (Lessig, 2001). The one that is most prevalent is involves unlawful book reproduction. The next form is that of publication of books by a different author but then inscribing the name of a prominent author in order to improve sales. A variation of this form of piracy is whereby the pirate obliterates the name of the author and inserts another name with or without altering the content of the book. The last type of piracy involves production of translated editions of books originally written in other languages without recourse to the copyright owner.

A survey of literature revealed that book piracy has been portrayed in different ways depending on the nature and interest of the individual or group. The perspectives of those in the literary industry, open knowledge society, students, lecturers and Librarians; low income 
groups and civil disobedience groups are discussed below.

\subsubsection{Literary Industries}

People in the literary industries link book piracy to theft, depicting the perpetrators of the act as criminals who steal the outputs from other peoples' hard work, talents, skilfulness and investments (Charman-Anderson, 2013). This viewpoint is premised on the fact that pirates spend little or nothing on overheads and other factors of production, they merely lay hands on an original copy of a work and reproduce it.

\subsubsection{Open Knowledge Society}

Those who classify themselves as coming from the open knowledge society view book piracy as just an expression of the saying that information begs for freedom (Waigner, 2003). They reason that the information created by authors is meant to benefit other people and hence they should share it selflessly. In a socialist utopia, information ideally contains no special value (Kunz, 2001). Hence, contravention of this value and belief by trying to sell information justifies infringement of copyright. They argue that protecting knowledge causes immeasurable destruction to creativity, learning, research, free exchange of information, and for drug patents, it can lead to loss of lives (Lessig, 2001). The drawback of this view is that authors, publishers and distributors are unable to continue working without incentive since their works contain legitimate value they deserve returns on their time and effort.

\subsubsection{Students, Lecturers and Librarians}

Librarians, most students, their parents and teachers, see piracy in a positive light. According to this group, piracy provides the only functional method of accessing content, since books are usually unavailable on the formal market or when a prescribed reading is only one chapter of a book then the student cannot buy the whole book only to read that particular chapter. In Zimbabwe, schools experience scarcity of fundamental textbooks, with researchers reporting figures of eight (Ndawi, 1997), 20 (The ZimDiaspora, 2013) and up to 40 (IRIN, 2009) pupils that share a single book. In such cases some people end up having no choice but to photocopy the scarce books.

\subsubsection{Low Income Group}

For those with low incomes, authentic books cost far more than they can afford whilst pirated books are affordable. In Zimbabwe cases have been cited were an original book may cost as much as ten times the cost of a pirated one (AFP, 2012). In a country were many parents/students are unemployed and those that are employed earn salaries below the poverty datum line (Antonio, 2013), pirating has become the norm. It is therefore not surprising that book piracy activities predominate in Zimbabwe given that books are very costly.

\subsubsection{Civil Disobedience Group}

Some people support and view book piracy just as an objection against what they consider as the bad hegemony of the literary industry. Young (2008) reported that the founder of the Textbook Torrents website goes out of his way to assist internet users in downloading copies of 
textbooks online illegally as a way of protesting against the dominance of the literary industry. Similarly, some pirates are interested in the "thrill of the hunt", by embarking in the sport of being information terrorists and evading law enforcement. They enjoy the thrill that they rarely get caught by law enforcement agents (Petrovich, 2001).

\subsection{Why Is Book Piracy Unethical?}

The following factors make book piracy not only illegal but also unethical.

- The pirate never publishes a new book.

- The pirate does not pay any compensation or royalties to the copyright owner or to the legitimate publisher.

- The pirated books are often of inferior quality; although this might not be a cause for concern for fiction, high quality is required for text books; for example surgery textbooks containing poorly reproduced figures, pictures, drawings, and illustrations tend to be dangerous and misleading to students. However, it should be noted that with current technology printing and photocopying quality can be very good, rendering pirated products indistinguishable from the original.

- Pirates do not take any financial risks, preferring to focus on products on high demand.

- Acts of piracy also have an effect of reducing governments' revenue as a result of evaded taxes.

\section{Methodology}

The study used document analysis, observation and face to face interviews with key informants as sources of data. The author has worked within the higher education sector for over 20 years and has an in-depth understanding of the issues relating to copyright infringement in that sector. The data was collected over a period of four months in 2013. The documents used in the study included intellectual property laws, government policy documents as well as literature search for books, chapters in books, Journal articles and conference/workshop papers and newspaper articles on book piracy. Seventy-five key informants which included 6 government officials, two each from the Ministry of Higher and Tertiary Education, Science and Technology Development, Ministry of Primary and Secondary Education, Ministry of Justice, Legal and Parliamentary Affairs, 5 officials from the Zimbabwe International Book Fair leadership, 3 publishers, 5 authors, 5 university Librarians, 5 university Lecturers, 10 parents, 25 university students and 9 book vendors.

\section{Results and Discussion}

The findings of the study were grouped into four sub-headings namely: The types of book piracy prevalent in Zimbabwe, the causes of book piracy, the effects of book piracy and the suggested strategies to combat book piracy. 


\subsection{Types of Book Piracy in Zimbabwe}

The findings of the study revealed that unlawful reprography and abuse of publication rights are the main forms of book piracy in Zimbabwe. This involved illegal reproduction of copyrighted literary material through scanning, photocopying, printing and electronic duplication of textbooks, set books, novels, fiction, poems and other scholarly works. In fact this form of book piracy has become almost the norm as evidenced by the number of copies sold at very low prices though an organised system of street vendors (AFP, 2012; NewZimbabwe.com, 2013; Radio Netherlands Worldwide Africa, 2012) as well as rampant photocopying of books by students, their parents and teachers. The findings revealed that although the major end users of book piracy activities are staff and students in schools and institutions of higher learning, illegal printers, commercial reprographers, distributors and vendors were actively involved. This finding is in agreement with Isiakpona, (2012) who noted that book piracy is perpetuated a whole chain made up of information users, commercial reprographers and bogus printers.

\subsection{The Causes of Piracy}

The causes of book piracy were identified as book scarcity, poverty and ignorance as well as poor enforcement of the copyright laws.

\subsubsection{Book Scarcity}

The shortage of books both at secondary and tertiary level was ranked as the key cause of book piracy. The scarcity of books in Zimbabwe has left information users with no option but to resort to use of pirated literary material. This provided an opportunity for reprographers, printers and distributors to make a killing.

\subsubsection{Economic Factors}

The factor that was ranked second in contributing to book piracy was the unavailability of disposable cash. Most parents and students were either unemployed or were earning salaries below the poverty datum line thereby rendering them incapable of affording expensive reading material. One university student respondent was quoted saying as it is my parents are struggling to pay for my tuition and living expenses, let alone afford expensive books.

Other respondents considered the unreasonably high cost of original books to be the cause of the problem. They argued that for instance, a 50-page book imported from countries like China has a landing cost of less than US\$2 in Zimbabwe, whilst a similar book produced in Zimbabwe costs more than US\$10. A pirate can easily produce illegal copies of the book and sell it for US\$4. It is no wonder that economically rational buyers go for cheaper books. However, when original books are sold at an affordable price, many people prefer them over the pirated copies.

\subsubsection{Issues of Copyright Law}

Respondents submitted that the third reason why book piracy is rampant in Zimbabwe has been the inadequate and ineffective enforcement of copyright laws. Despite the fact that Zimbabwe 
has in place, the relevant legal framework and intellectual property policies, weak enforcement remains one of the greatest hindrances to curbing piracy. In the first instance, no one is sure of exactly who should do the policing of pirate activities. A report by Matsika (2006), of the Zimbabwe University Libraries Consortium (ZULC) indicated that in their case as Librarians, it was not clear whether they should be held responsible for policing clients to check what they do with the books they borrow. Secondly, the Zimbabwe Republic Police (ZRP) has been blamed for concentrating on chasing only pirates selling music products whilst ignoring those who sell pirated books. Mushava (2013) also questions why book pirates are allowed to operate in broad daylight without any serious measures to stop them, whilst other crimes, trivial or serious, are foiled immediately. However, according to ZRP informants, the police can only act when they have adequate information; in addition, they require a report from infringed parties before charging the offenders. In some cases police can arrest vendors of pirated books but if the owner of the copyrights does not come forward to act as a complainant, lodge a report and to prove that the books are pirated, there will not be any grounds to prosecute the suspected pirates. Lawyers that were interviewed confirmed this position, indicating that the Zimbabwean Constitution bars the ZRP from indiscriminately detaining books vendors without clear evidence that the books are pirated.

Factors such as limited public awareness, curriculum issues, corruption and red tape make it difficult to effectively enforce intellectual property laws Zimbabwe as outlined below.

\subsubsection{Public Awareness}

The study found out that members of the Zimbabwean public are not knowledgeable about issues to do with the laws governing intellectual property in the country. In fact the current regulations are not easily accessible even to intellectuals and academics as evidenced by the research by Matsika (2006) who reported a lack of awareness of intellectual property issues in institutions of higher education.

\subsubsection{Curriculum issues}

Documentary evidence revealed that only two (University of Zimbabwe and Midlands State University) of the 15 registered universities in Zimbabwe offer degrees in Law. However, the curriculum does not include adequate courses on intellectual property. Moreover, none of the two universities has students that specialise in intellectual property. The number of lawyers who have expertise in this field in Zimbabwe, are also very few. Furthermore, university libraries are not resourced with basic intellectual property reading material.

On an encouraging note, since 2008, Africa University (a pan African university based in Zimbabwe) has been offering a Masters degree in Intellectual Property at its Peace, Leadership and Governance Institute. This degree is offered jointly with the World Intellectual Property organisation (WIPO) Academy, a United Nations agency based in Geneva and the African Regional Intellectual Property Organisation (ARIPO) based in Zimbabwe with support from the government of Japan (http//www.africau.edu/news/intellectual.html). 


\subsubsection{Corruption}

Corruption was reported to be on the increase in Zimbabwe. According to the Transparency International Corruption Perception Index, Zimbabwe was ranked 154 out of 182 countries surveyed in 2011 and in 2012, Zimbabwe had an overall rank of 163 out of 176 countries assessed (Transparency International Zimbabwe, 2013). Corruption hampers the proper enforcement of intellectual property laws. It is not uncommon to see a senior law enforcement officer practising piracy. In this case the paradox who will guard the guards comes to the fore. Intellectual law enforcement agents should include on security personnel, Municipal Police, Heads of education institutions, Teachers/Lecturers, Librarians, the Zimbabwe Republic Police and the Zimbabwe Revenue Authority.

\subsection{The Effects of Book Piracy}

The findings revealed that cities, towns and district centres in Zimbabwe are swamped with low-quality pirates books selling at considerably reduced prices compared to those pertaining in bookshops. Mushava, (2013) reported that pirated copies of books go for less than half the original ones, thereby creating a potential collapse of the formal sector given that most buyers are thrifty.

According to the respondents, the impact of book piracy was positive as far as the beneficiaries (commercial reprographers, illegal printers, vendors and information users) were concerned but had debilitating effects to the copyright owners (authors, publishers and distributors). One key informant was quoted saying, I can easily compare book piracy to a double-edged sword. From the author and publisher's perspective, piracy is implies loss of revenue particularly because the majority of authors do not make much money from their works and publishers invested funds in getting the books published. On the other hand, when viewed from the perspective of people responsible for promoting reading and learning, piracy amounts to more books available, which is not a bad thing. This assertion is buttressed by the report by Radio Netherlands Worldwide Africa (2012), which revealed that whilst books in Zimbabwe have become cheaper for cash-strapped but education-hungry citizens as a result of acts of piracy, publishers, distributors and writers are watching their earnings vanish due to escalating book piracy.

\subsection{Strategies to Combat Book Piracy}

The major challenge reported is on how to eliminate piracy. The major huddle comes from the fact that pirates are ingenious and they stay a step ahead of law enforcement authorities most of the time. The system that they operate in is very intricate, it involves use of skills and dexterity to create, hide and supply pirated products using regulated markets. The second challenge comes from the high costs involved and resources needed in instituting anti-piracy measures. Therefore it was suggested that the most effective anti-piracy strategy is for all stakeholders to join hands in reducing piracy thereby building a thriving legal marketplace. This will enable the literary business to become more robust, more 'future-proof', and customers will be treated to a high level of care and quality service. That should always be the literary industry's number one priority. The goal should be to protect the creativity and the viability of the book industry. 
In order to achieve this goal a combination of the following control measures can be used awareness and advocacy; technology; creative pricing, distributing and promoting; reinforcement of intellectual property laws; and innovative monitoring and regulating strategies.

\subsubsection{Awareness and Advocacy}

Providing information to the public in an effort to effect a positive change in their attitudes is likely to be of great help especially with respect to piracy acts related to photocopying beyond what is permissible within the copyright law. However, awareness campaigns are become ineffective because most of the time consumers of pirated literary material trust that they are buying authentic or second hand books. Closer co-operation amongst all stakeholders is of great importance in squashing the activities of pirates. Initiatives to encourage greater information exchange within the society and exercising vigilance will go a long way in detecting piracy.

\subsubsection{Technological Solutions}

It is possible for the literary industry to use advanced technology that can assist consumers in distinguishing between genuine and pirated material. One example will be to use watermarks which reveal clear marks or words when the genuine material is duplicated. Authors can also resort to publishing electronic books, which can be encrypted with powerful codes that permit online access to subscribers only.

\subsubsection{Innovative Pricing, Distribution and Promotion}

The literary industry needs to be innovative enough so that their clients can be encouraged and can afford to purchase legitimate reading material, instead of just downloading them for free, photocopying them or buying pirated copies. It is important to experiment with innovative options that pirates simply cannot match.

There is need for authors and publishers to create direct relationships with readers so that they can give them reasons, to buy from them and not from pirates. Another way to reduce prices of books is to include advertisements from companies and entities willing to sponsor. These advertisers will then pay a free which will help reduce costs of producing the material or book leading to a reduction in the price of books for consumers.

\subsubsection{Strengthening and Enforcement of Intellectual Property Policy}

Although the relevant legal framework and intellectual property policies exist in Zimbabwe, the law enforcement is weak and should be strengthened. This can only be possible when all stakeholders work together to help curb book piracy. For example the public can assist in providing information on activities of piracy to the police who will in turn arrest the offenders. The copyright owners also need to be vigilant in detecting and reporting on their pirated works. In addition, adequate resources need to be availed. The government needs to act decisively on reducing corruption and red tape. 


\subsection{Recommendations}

It is not simple to deal with issues of book piracy since policies alone have proved to be insufficient and ineffective. There is need for all stakeholders to actively play their part. The contribution of higher and tertiary education institutions will include the following

Academic staff, university management and Librarians should spearhead in making sure that students are made aware of intellectual property and copyright laws. New students could be involved in these awareness campaigns as part of their orientation programmes. Lecturing staff should continue to raise awareness during contact periods through the inclusion of copyright laws in the curriculum. Introduction of curriculum relating to intellectual property, for example the one offered by Africa University, is encouraged. This would greatly assist not only in enhancing students' awareness of the consequences of infringing the laws but will also motivate compliance thereby reducing acts of piracy.

University libraries need to be well resourced with adequate and appropriate literary materials. These should be easily accessible and available to students, lecturers, researchers and other readers when required, thus reducing the need to photocopying. The librarians should make sure that multiple copies of books and other learning materials are available in the library to allow many users to make use of the materials simultaneously. Librarians should always purchase genuine reading material and should negotiate with suppliers so that they procure cheaper reading materials. Librarians and university management should ask photocopying agents to pay royalties for excessive photocopying done within the university premises.

\section{Conclusion}

Book piracy is threatening the continued success of the literary industry in Zimbabwe. Accordingly, all stakeholders should work towards the protecting intellectual property. Although it might not be possible to purge piracy, combined stakeholder efforts will benefit holders of copyrights and the literary industry as a whole. The ways in which the higher and tertiary education sector can contribute to reducing piracy include awareness, advocacy and enforcement of copyright laws; revitalization of libraries as well as practising curriculum inclusiveness.

\section{References}

AFP. (2012). Book piracy leaves publishers seething. Retrieved from http://www.newzimbabwe.com/news-9512

Antonio, W. (2013). Extra lessons or extra cash? Retrieved from https://www.newsday.co.zw/2013/04/20/extra-lessons-or-extra-cash/

Charman-Anderson, S. (2013). Piracy, Saviour of the Book Industry. Retrieved from http://www.forbes.com/sites/suwcharmananderson/2013/02/13/piracy-saviour-of-the-book-in dustry/

Cohen, B., (2009). How can publishers limit e-book piracy? Retrieved from $\mathrm{http} / / \mathrm{www} . c h a n n e l 4 . c o m /$ news/articles/arts_entertainment/books 
http//www.africau.edu/news/intellectual.html

IRIN. (2009). Zimbabwe: US\$70 million to help resuscitate education. Retrieved from http://www.irinnews.org/report/86177/zimbabwe-us-70-million-to-help-resuscitate-education

Isiakpona, C. D. (2012). Undergraduate Students' Perception of Copyright Infringement: A Case Study of the University of Ibadan, Oyo State, Nigeria. Retrieved from http://www.webpages.uidaho.edu/ mbolin/isiakpona.htm

Lessig, L. (2001). The Future of Ideas: The Fate of the Commons in a Connected World. Random House, New York, NY.

Kuntz, L. I. (2001). Pirates and the paper chase. The UNESCO Courier, 54(3), 41-42.

Matsika, K. (2006). Intellectual Property and Access to Information in Zimbabwe. A paper presented at the ZULC Conference on Intellectual Property in April 2006. Retrieved from http://ir.uz.ac.zw/jspui/bitstream/10646/359/3/Matsika-ZULC-Conf-INTELLECTUAL-PRO PERTY-Paper-April-2006.ppt.txt

Mushava, S. (2013). Piracy upends book sector. Retrieved from http://www.herald.co.zw/piracy-upends-book-sector/

Ndawi, O.P. (1997). Education for all by the year 2000 (EFA 2000) in some countries in Africa: Can teacher education ensure the quantity, quality and relevance of that education? International Journal of Educational Development, 17(2), 121-128. http://dx.doi.org/10.1016/S0738-0593(96)00025-9

The ZimDiaspora, (2013). What has Mugabe and Tsvangirai done for Zimbabwe? Retrieved from

http://www.zimdiaspora.com/index.php?option=com_content\&id=10539: what-has-mugabe-ts vangirai-done-for-zimbabwe $\&$ Itemid $=18$

NewZimbabwe.com. (2013). Book piracy leaves Zimbabwe publishers seething. Retrieved from

http://www.newzimbabwe.com/news-9512-Book\%20piracy\%20leaves\%20publishers\%20see thing/news.aspxhttp://www.thezimbabwean.co.uk/entertainment/art-and-literature/51268/thie ves-arrested-for-book-piracy.html

Petrovich, F. (2001). Chile: a judge steps in. The Unesco Courier, 54(3), 43.

Phiri, B. (2013). Zimbabwe: ZIBF Denounces Book Piracy. Retrieved from http://allafrica.com/stories/201310030751.html

Popoola, T. (1991). Piracy and the Nigerian Educational system.

Radio Netherlands Worldwide Africa. (2012). Book piracy leaves Zimbabwe publishers in red. Retrieved from http://www.rnw.nl/africa/bulletin/book-piracy-leaves-zimbabwe-publishers-red

Thomas, A. (1991). Copyright and the future of publishing, particularly electronic publishing. 
The Publisher, 2(1).

Transparency International Zimbabwe. (2013). ZACC incapacitated to fight corruption Retrieved from http://www.transparency.org.zw/index.php/component/content/article/44-programmes/93-regi onal-advocacy

Waigner, R. P. (2003). Information wants to be free: Intellectual property and the mythologies of control. Retrieved from https://www.law.upenn.edu/fac/pwagner/wagner.control.pdf

Young J. R. (2008). Founder of Textbook-Download Site Says Offering Free Copyrighted Textbooks is Act of Civil Disobedience. Retrieved from http://chronicle.com/blogs/wiredcampus/founder-of-textbook-download-site-says-offering-fre e-copyrighted-textbooks-is-act-of-civil-disobedience/4064

\section{Copyright Disclaimer}

Copyright reserved by the authors.

This article is an open-access article distributed under the terms and conditions of the Creative Commons Attribution license (http://creativecommons.org/licenses/by/3.0/). 